\title{
Educating teachers towards global citizenship: A comparative study in four European countries
}

\author{
Massimiliano Tarozzi* - UCL Institute of Education, UK \\ Benjamin Mallon - Dublin City University, Republic of Ireland
}

\begin{abstract}
This article, derived from a larger EU-funded empirical research project, draws on a comparative analysis of pioneering global citizenship education (GCE) inservice primary teacher education programmes, as theorized and practised in four European countries, to explore how higher education institutions (HEls), non-governmental organizations (NGOs) and participating teachers shape the development of content-based, competence-based and values-based approaches to teacher education. With reference to the multiple-site case study in Ireland, Austria, the Czech Republic and Italy, this article argues that, through investment, structural and institutional support and professional teacher education expertise, HEls are, alongside NGOs and in-service teachers, pivotal actors in the collaborative development of GCE teacher education. The article concludes that successful collaborations can foster teacher agency through transformative, values-based approaches to GCE teacher education.
\end{abstract}

Keywords: global citizenship education; teacher education; multi-stakeholder collaboration; comparative education; teacher agency

\section{Introduction}

Formal education has increasingly been positioned as a space for the development of global citizens who, with a deep understanding of global issues, are committed to transforming the complex and deeply unequal interconnections between individuals and societies around the world (Bryan, 2012; Davies et al., 2018). However, the concept of global citizenship has been criticized as nebulous and divorced from the realities of education within the Global South (Jooste and Heleta, 2017), imperceptive to gender relations (Tormey and Gleeson, 2012) and unobtainable for those for whom national identity, through which global identity is refracted, is insecure $\left(\mathrm{O}^{\prime} \mathrm{Connor}\right.$ and Faas, 2012; Pashby, 2011). Yet, scholars such as Davies (2006), Tarozzi and Torres (2016) and Shultz (2007) argue that forms of global citizenship can support a transformational agenda and the pursuit of global social justice.

Global citizenship education (GCE) policy across Europe has become increasingly framed by the growing displacement of people fleeing violence and environmental disaster across European borders, a rise in right-wing populism across the continent and the threat of terror and radicalization (GENE, 2017). Across Europe, governments have added GCE to educational curricula (Goren and Yemini, 2017; O'Connor and Faas, 2012; Tarozzi and Inguaggiato, 2018), but the forms that it takes vary. In the United Kingdom, the roots of GCE can be connected to the promotion of global education 
and world studies (Bourn, 2015; Davies, 2006; Osler and Vincent, 2003; Pike and Selby, 1988; Richardson, 1979). As elsewhere in Europe, GCE merged several themes under the same notion, or at least under the same vague umbrella term, encompassing development education, environmental education and citizenship education, and their related topics (Fricke et al., 2015; Mannion et al., 2011).

To put it simply, there is clear tension between two dominant perspectives on the objectives of GCE: a perspective that views GCE as the preparation of students for competition within the globalized world of work (Hartung, 2017; Schattle, 2008) stands in conflict with a perspective that views GCE as a vehicle for challenging global inequality (Bourn, 2015; Davies, 2006). In fact, criticism of the former argues that individualized entrepreneurial forms of GCE serve to perpetuate global inequality and reinforce the negative effects of globalization (Biccum, 2010; Shultz, 2007) and Eurocentric colonial privilege (Andreotti, 2006).

This article explores the involvement of higher education institutions (HEls) alongside non-governmental organizations (NGOs) within the provision of teacher education for GCE. Drawing on a European research project exploring the provision of teacher education in four countries, this article argues that, in providing structural and institutional support and investment in addition to professional teacher education expertise, universities are positioned, alongside NGOs, as pivotal actors in the collaborative development of GCE teacher education. We argue that successful collaborations can foster teacher agency through transformative, values-based approaches to GCE teacher education.

\section{Teacher education for global citizenship: A literature review}

Against the worldwide expansion of higher education, GCE has become an increasing concern for HEls (George-Jackson, 2010; Stein, 2015). Universities have made explicit connections to the processes of globalization and internationalization (Engel and Siczek, 2018; EUA, 2013). Both Hammond and Keating (2018) and Friedman (2018) suggest that governments and universities, including those within the UK, are under increasing pressure to internationalize both their practice and their student cohort, while developing their global reach within a global framework of neo-liberal economic policies and practices. This engagement with global citizenship has received increasing scrutiny, leading to accusations that HEls are overly concerned with the development of employability within the global marketplace, rather than with fostering global citizens with a deep understanding of the injustices of globalization and the competencies to affect positive societal change (Hammond and Keating, 2018).

Across Europe, universities are recognized as playing an important role in the provision of GCE through teacher education programmes (GENE, 2017). Policymakers have become interested in GCE teacher education (Bryan and Bracken, 2011), as further evidenced by UNESCO's (2017) Global Education Monitoring Report and its inclusion with the Sustainable Development Goal indicator 4.7.1 (United Nations, 2015). However, teacher education practices in this regard remain underexplored, with much of the current literature concerned with classroom practice and the experiences of teachers. Within schools in the UK, Davies et al. (1999) identified that forms of citizenship are conceptualized as apolitical and addressed in a highly localized manner. Teachers in the UK may avoid complex global issues (Steiner, 1992, cited in Robbins et al., 2003: 93), and some may similarly have a reluctance to teach 
about content perceived as controversial (Davies et al., 1999). Further research in the UK highlights the lack of teacher education in relation to global issues, which constrains confidence, classroom practice and the negotiation of personal views (Davies et al., 2005; Holden and Hicks, 2007). In reviewing recent worldwide literature on GCE implementation in schools, Goren and Yemini (2017) observe that teachers attribute vagueness to the term 'GCE'. This can be a consequence of scholars' ambiguity towards GCE, but also of the fact that goals associated with GCE are also often unclear (ibid.). Many teachers express positive attitudes towards GCE (McCormack and O'Flaherty, 2010), yet although such motivation may underpin effective practice (Holden and Hicks, 2007), several barriers remain. Summarizing their systematic literature review of GCE, Goren and Yemini (2017: 179) conclude that 'teachers and educators recognize the importance of GCE; however, they often feel trapped between curricular goals encouraging its incorporation in the classroom and cultural norms of nationalism or lack of practical resources that hinder their ability to actually teach it'. Research identifies that teachers express concern for inadequate teaching tools and resources (Appleyard and McLean, 2011; Carr et al., 2014), and may perceive themselves as ill-equipped and therefore likely to avoid complex global issues (Niens et al., 2013). Within the Irish context, perceptions of limited resources, limited personal expertise and low teacher confidence hinder more critical classroom engagement with global issues (Clarke and Drudy, 2006; Holden and Hicks, 2007; McCormack and O'Flaherty, 2010). Although teacher education is viewed as a means to support teachers in developing confidence and competence to address GCE in the classroom and to integrate GCE into whole-school approaches (Robbins et al., 2003), the role of teacher education in fostering individual and social transformation within schools and classrooms remains underexplored.

It is recognized that teacher education approaches addressing GCE involve diverse stakeholders. A recent comparative policy analysis confirms that NGOs play a significant role as political actors in GCE policymaking, while at the same time providing in-service teacher education and stimulating initiatives for pre-service teacher education (Tarozzi and Inguaggiato, 2018). These results echo a current debate about the political role of international NGOs as 'new global civil society' (Castells, 2008; Kaldor, 2003) and their involvement in implementing GCE policy at national level (Witteborn, 2010). Research also reveals the complexity of the relationships between NGOs and other actors (Jaeger, 2007; Tota, 2014). Furthermore, as universities are increasingly recognized as important actors within the collaborative provision of GCE through teacher education (GENE, 2017), a deeper exploration of the roles and actions of stakeholders involved in the emerging field of teacher education for global citizenship is required.

\section{Methods}

\section{Research design and data collection}

Located within a multiple-site case study design (Yin, 2014), this two-year (2016-17) research study explored eight pioneering teacher education settings in four European countries (Austria, the Czech Republic, Ireland and Italy). These countries each had recognized national strategies for GCE, and provided a range of levels of political GCE implementation. In each country, two settings were selected: (1) a programme internal to the broader project, a teacher education programme for in-service primary school 
teachers funded by the European DEAR (Development Education and Awareness Raising) programme; and (2) a programme outside of the project addressing themes related to GCE but organized by an external organization. Extreme case sampling was employed to remain open to the selection of teacher education programmes that could be considered both typical or unusual (Palinkas et al., 2015).

The project adopted ethnography as an overall methodological approach for data collection and analysis. Across the four phases of the data-collection process (gaining access to the field; preliminary round; open observation; focused observation), six types of data were collected:

1. field notes of observations of primary school teachers' teacher education sessions and of planning meetings among course organizers (approximately 300 hours of observation and 123,991 words of transcription)

2. formal semi-structured interviews, transcribed verbatim, with both with teacher educators and course promoters (21 interviews)

3. informal interviews with key informants during observations and recorded within field notes (24 interviews)

4. projects documents, such as course leaflets, course resources and other course materials (120 documents)

5. visual data (pictures) taken during the teacher education sessions ( 80 items)

6. participating teachers' open-ended questionnaires administered before and after sessions (200 questionnaires).

\section{Data analysis}

Data have been examined using two analytical strategies:

1. inductive analysis producing a codebook encompassing a conceptual organization of the main emerging themes, subsequently used to code all data

2. 'thick' descriptive analysis of national cases.

Primarily, a content analysis on a significant section of data taken from across the eight case studies was carried out. Through collaborative analysis, codes and themes were identified, and a common codebook was developed. The codebook, tested by independent coders to ensure reliability and credibility, is an inductive result per se. It provides a definition of every broad category, thus guiding all researchers in the content analysis of all data. Through a systematic coding of all the data collected in each country, 9 themes and 32 sub-themes were identified, each carefully defined by the research team; 3 major themes emerged as most meaningful, based on the frequency of occurrences and on their conceptual density across the multiple sites under investigation:

1. 'GCE conception': the different conceptualizations of GCE that actors contributing to the organization and implementation of the course have in mind.

2. 'Teaching approaches': the principles, pedagogy and management strategies used for classroom instruction.

3. 'Contrasting cultures': the different perspectives, world views and beliefs held by stakeholders, and the resulting intergroup conflicts and tensions between cultures.

In this article we focus on 'Teaching approaches' through the lenses of the different perspectives highlighted in the theme 'Contrasting cultures'. 


\section{Findings}

\section{A network of actors in the development of teacher education for global citizenship}

There are a range of different actors involved in the process of teacher education for global citizenship, with similarities in each of the four countries. An overview of these common actors can be seen in Table 1.

\section{Table 1: The roles of actors involved in GCE teacher education}

\begin{tabular}{ll}
\hline Actor(s) & Role \\
\hline Funding body & Provision of funding to programme organizers \\
Government/local authority & $\begin{array}{l}\text { Development of statutory requirements that shape } \\
\text { provision of teacher education }\end{array}$ \\
Teaching unions & $\begin{array}{l}\text { Provision of information and advice, through extensive } \\
\text { network, which shapes educational practices }\end{array}$ \\
NGOs & Expertise in development and education \\
HEls & Expertise in educational research and teacher education \\
Teachers/trainees & Participation in programmes \\
Teacher educators/trainers & Design and facilitation of programmes \\
\hline
\end{tabular}

In each country, funding bodies are a major driver of teacher education, providing vital financial support for programmes. Governmental and local authorities provided policy frameworks across each of the European contexts and within the Irish and Austrian contexts, and were perceived to play an important role in the structure and design of programmes. Other actors, such as schools, parents and children, were also identified as of note in the broader study.

Beyond teachers, two groups appeared as pivotal in the development and practice of programmes. NGOs served as both a source of knowledge in relation to the issues addressed within programmes, and at times, as a source of expertise in relation to the educational approaches utilized. Also playing an important role in the design and delivery of programmes, HEls were recognized as important actors in each country. These HEls served as teacher education specialists with strong connections to educational research.

HEls were identified as collaborators in six of the eight teacher education programmes explored within this research (see Table 2). In one Austrian programme, the $\mathrm{HEI}$ was the sole institution behind the development and delivery of the teacher education programmes. In four of the other cases, HEls worked in collaboration with NGOs. The work of HEls and the relationships between HEls, as part of the formal education system, and NGOs emerged as an important focus for this study.

Table 2: Teacher education providers across European cases

\begin{tabular}{lll}
\hline Country & Programme A & Programme B \\
\hline Austria & $\mathrm{HEl}$ and NGO & $\mathrm{HEI}$ \\
Czech Republic & $\mathrm{NGO}$ & $\mathrm{HEl}$ and NGO \\
Ireland & $\mathrm{HEl}$ and NGO & $\mathrm{NGO}$ \\
Italy & $\mathrm{NGO}$ & $\mathrm{HEl}$ and NGO \\
\hline
\end{tabular}


Everywhere, collaboration between actors was perceived as a necessary or even positive feature of a successful teacher education, as the Austrian case shows: 'appreciation of different, diverse opinions and approaches is central in the concept of the teacher training' (Austria, document, September 2016). Documentation from the Italian case also expresses a positive perception towards the potential of collaboration between the different actors within teacher education: 'The module starts with an awareness that global citizenship education cannot be the exclusive responsibility of the school but needs a network of multiple actors: associations of $\mathrm{NGOs}^{\prime}$ (Italy, document, October 2016).

Within such an example, the responsibility for successful GCE teacher education is posited as a collective endeavour by the formal education system and NGOs. From the same teacher education programme, documentation highlights how such a shared obligation might be achieved, by 'opening spaces for teachers and NGO practitioners to be trained together so that they can share perspectives and methodologies' (Italy, document, November 2016). This emphasis on collaboration was also clear from an informal interview within the Czech case, with reference to the 'emphasis on development of cooperative and caring thinking ... vital for GCE' (Czech Republic, field notes, January 2017).

\section{A triumvirate of pedagogical narratives for teacher education for global citizenship}

As mentioned above, from the inductive analysis, three major themes emerged as most meaningful, namely 'GCE conception', 'Contrasting cultures' and, of particular importance within this article, 'Teaching approaches'. The comparative frequency of codes associated with the theme of 'Teaching approaches' and its associated subthemes can be seen in Table 3.

Table 3: Frequency of codes within theme 'Teaching approaches'

\begin{tabular}{lccccc}
\hline Theme/Sub-theme & \multicolumn{5}{c}{ Country } \\
\hline Teaching approaches & 4 & 21 & 0 & 0 & 25 \\
Aims and goals & 58 & 3 & 27 & 60 & 148 \\
Trainee assessment & 18 & 35 & 37 & 158 & 248 \\
Classroom climate & 62 & 87 & 12 & 23 & 184 \\
Teaching methods & 73 & 57 & 5 & 134 & 269 \\
Pedagogical/theoretical & 24 & 6 & 54 & 95 & 179 \\
approaches & 16 & 7 & 62 & 9 & 94 \\
Classroom setting & 28 & 14 & 26 & 74 & 142 \\
Activity & & & & Ireland \\
\hline
\end{tabular}

In focusing our discussion on 'Teaching approaches', three main interconnected narratives emerge. These narratives are illustrated in Figure 1, as values-based, contentbased and competence-based approaches to teacher education. More specifically, those involved in the development and delivery of teacher education programmes introduce a third pole in the content-values dichotomy that typically represents a traditional and a transformative pedagogical approach: the concept of competence. 


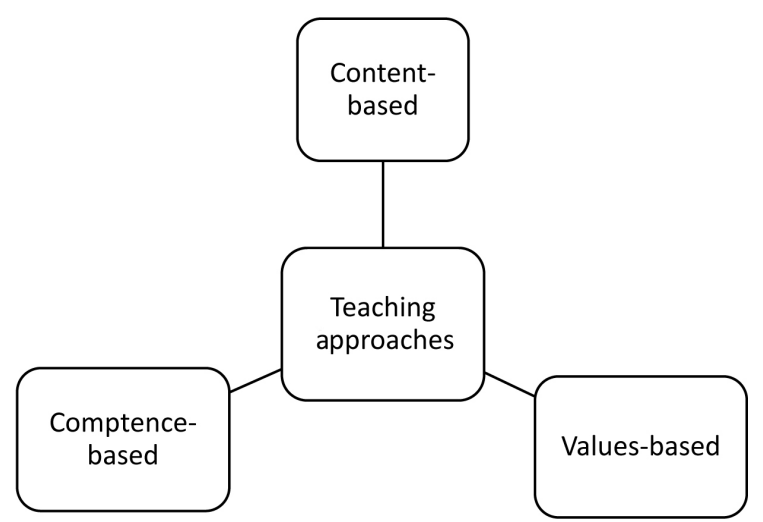

Figure 1: Triumvirate of pedagogical narratives

Analysis across each of the programmes within the four countries revealed a mainstream narrative that positioned approaches to teacher education in one of two opposite rhetorical poles: a traditional schooling approach, based on content and its transmission, ethically neutral and centred on learning; and an engaged approach, grounded in values, aimed at eventually educating students according to a set of ethical or even political principles. This second, values-based teacher education narrative appears aimed at engaging teachers to embrace values or to activate them to promote individual and social transformation and students' emancipation. In addition to these two narratives, however, data reveal a third perspective on teacher education. This can be viewed as competence-based, where teaching subject content is closely connected to the way in which people learn.

It is important to note that these dimensions are not always mutually exclusive, especially in the more elaborate courses, where content, competence and values dimensions are intertwined and simultaneously integrated in the same teaching process. The article will now consider these dimensions in greater depth, with a focus on the roles of HEls, NGOs and participating teachers in the integration of these approaches into teacher education practice.

\section{Content-based approach}

While this is the least frequent pedagogical narrative across the data, it is still predominant at least in two cases. It is perceived as transmissive, teacher-centred, and based on a factual presentation of topics such as history or legislation. For example, within the Czech case, a teacher education programme document gave a course description that stated: 'The main goal of the course is to transmit GCE and its fields of competences as well as GCE didactics and methods to be able to implement the dimensions of GCE in their own classroom practice' (Czech Republic, document, September 2017). Observation notes from the programme highlight the pedagogical approaches enacted within aspects of this programme:

The lecture-type seminars are based on transmissive pedagogy. The trainer is at the centre of attention; participants address him/her when they want to ask or add something. The trainer shared his/her knowledge and experience. The arrangement of chairs and tables in school-like rows is suitable for this type of seminar and it had been prepared before the lecture took place. (Czech Republic, field notes, March 2017) 
Otherwise, issues addressed within teacher education programmes appeared to depend on the specialism of the teacher educators and their associated organizations, whether that be universities or NGOs. For example, within the Austrian context, issues such as racism, discrimination and migration were prioritized within one programme, driven by a sense of collective responsibility considering a colonial past (Austria, field notes, June 2017). Within the Czech case, climate change, inclusion and human rights were identified as specialisms. Within the Irish context, an NGO partner's specialism in migration offered important input into aspects of one teacher education programme. Within the Italian context, a specialist focus on migration and food was apparent (Italy, formal interview, December 2016) but also a perception that NGOs had originally been used 'to bring testimonies from Africa or Latin America but then [they] started to change and bring a more formative intervention and not only a witness from the south of the world' (Italy, formal interview, December 2017). The collaboration between the $\mathrm{NGO}$ and $\mathrm{HEl}$ in this case had fostered content-oriented seminars where the aspects of the programme dealing with history and legislation were presented as a factual piece.

\section{Values-based approach}

In the values-based approach, the main goal appeared to be fostering change in teachers' attitudes. Here, values, beliefs or an ethos are important aspects to be developed throughout teacher education programmes. Such an approach is aimed at engaging teachers to embrace values or to activate them to promote school change, and content is functional to promoting commitment and engagement in teachers. To this end, the experiences and the classroom atmosphere are more important. In Austria, for example, one of the course's main aims:

is to build a reflective agency grounded on crucial GCE competencies like critical thinking, reflecting one's own values, finding creative solutions, dealing with complexity and ambiguity as well as identifying with issues like global justice, sustainability, human rights, democracy and intercultural learning. (Austria, field notes, May 2017)

Course organizers suggest that the priority for GCE teachers is to develop an ethos that makes them aware of their role in exercising solidarity and social and political participation at school. Even if more data are required to support this claim, evidence existed that suggested that, from the perspective of a teacher educator, participating teachers may also believe that a change in their own attitude is important:

Trainees mentioned several times that they see the change concerning their own attitude as highly important for the classroom, because if you as a teacher change your attitude you also deal differently with children's question and you can raise more consciousness among other teacher colleagues. (Austria, formal interview, February 2016)

In most of the cases, NGOs tended to adopt a values-based approach and focus on the affective, transformative and ethical dimensions of GCE (see also Oxfam, 2015). These elements represent both an opportunity and a threat: an opportunity, as working on teachers' values and beliefs empowers teachers' agency (Biesta et al., 2017), but a threat that if the affective and ethical dimensions are overemphasized, then less attention may be paid to knowledge and skills. 


\section{Competence-based approach}

The competence-based approach is the most coded item in this section (18 occurrences), but it is understood in very diverse ways. The term has been used 86 times (more in Italy than elsewhere), but in an elusive way depending on the different discursive contexts. Despite the ambiguity of the term, the methodological competence-based approach is well understood. Originally grounded in the World Health Organization (WHO, 1993) approach to life skills, it was widely promoted as 'key competences' by the Organisation for Economic Co-operation and Development (Rychen and Salganik, 2003) and the European Union (European Commission, 2007), and is subsequently often promoted by university teacher educators. On the one hand, it is understood as a teaching method, as in the Austrian cases, integrating the values dimension, identifying competences or skills such as critical thinking, finding creative solutions or dealing with complexity and ambiguity, and allowing teacher-students to build their own agency (Bourn, 2016). In this sense, 'the didactic competence is highly important to implement the approaches and knowledge in the classroom, to build on the living environment of the children, to create a motivating and creative learning environment through participation and dialogue' (Austria, document, September 2015)

On the other hand, competences are understood for their instrumental meaning when they provide a structured system of knowledge, skills and attitudes necessary to compete in a global context, and then they allow the objective measurement of the efficiency of this task, noted in the Italian context. Here the tension between two different visions and practices of GCE that was mentioned above becomes clear: teacher education aims at learning a pre-set list of competences that teacher-students in turn should be able to transmit to students in different settings. In this case, there is little or no space for values, and even less for promoting change and teacher agency. The following claim from a university teacher educator is emblematic: 'We do not test values that learners develop. We should train pupils to acquire the four competences and not teach them how to think' (Italy, formal interview, December 2016).

The ambiguity of 'competence' should be understood in relation to the different cultures of different actors. While knowledge of development issues was clearly important across each context, there was evidence of perceptions that classroom expertise was also essential in the development of teacher education programmes. Within the Italian case, it was suggested that teachers might perceive NGOs to be lacking in such expertise: 'What emerges from their attitude is that they think NGO educators have not a real experience in school activities and an adequate didactic preparation' (Italy, field notes, June 2016). A reason for scepticism may be identified in one Italian case, as an interview revealed a teacher's perceptions that, although they may bring important knowledge to education, NGOs 'should not substitute [for] teachers in class' (Italy, informal interview, June 2016).

Different actors embrace different approaches, based on what we call different cultures:

The researchers have the know-how on didactics by competence. NGOs bring the contents on citizenship, sustainable development etc. NGOs should provide those contents, that compose a crucial part of the didactic model, but they should not substitute [for] the teachers in class. (Italy, informal interview, June 2017)

Broadly speaking, the values dimension is more often enhanced by NGOs rather than university teacher educators with few exceptions (such as one course in Ireland and 
one in Austria), and so lays the foundation for the potential conflict between different pedagogical cultures. Likewise, as we mentioned before, some scholars outlined a potential conflict between the educational cultures of NGOs and schools, where the former may risk overemphasizing the affective and ethical dimensions and subsequently pay less attention to the cognitive dimensions (Marshall, 2005), as well as to knowledge and skills (Scheunpflug and Asbrand, 2006). The risk pointed out by some teachers is real in some contexts: to associate GCE-related activities with approaches that can be considered innovative, but also not typically academic, may lead to them being disregarded as extra-curricular. Others claim that NGOs have their own ethical and values base, sometimes blurred with fundraising and campaigning agendas (Bourn, 2015: 159), and often this vision does not seem to be negotiable.

\section{Discussion}

The findings of this article confirm that the main goal of teacher educators and the majority of analysed programmes within this study primarily rests with the achievement of teachers' agency (Priestley et al., 2015; Vongalis-Macrow, 2007) and with the work to empower them as agents of change (Fullan, 2003). A values-based pedagogical approach (usually stimulated and led by NGOs, but in some cases by HEls too) is a major driver in this process (Biesta et al., 2017) and in the engagement of teachers within the process of transformative practice.

Obviously, we are aware that the role of teachers as the sole agent of change has been shown to be problematic (Priestley et al., 2015), since there are other powerful structural constraints that teacher educators and policymakers should consider. Teacher education based on the mainstream culture of performativity, rigidly prescriptive curricula and oppressive regimes of testing (Biesta, 2010) tends to erode teacher agency. Therefore, NGO-driven values-based teacher education is highly valuable in developing transformative processes, engaging teachers to achieve positive agency towards school change. However, research also demonstrates that 'contrasting cultures' risk diminishing the effect of teachers' agency. Different theoretical, pedagogical and institutional cultures, especially between NGOs and teachers, could lead to conflict that undermines the effectiveness of constructive partnerships among different actors and diminishes the effect on teachers' agency. While dogmatic endorsement of one pedagogical approach from HEls, as seen in two of the programmes, may exacerbate such conflicts, in at least three of the cases observed, HEls facilitate negotiation between different pedagogical narratives, bridging contrasting cultures and divergent educational goals. However, within a particular case, there was recognition that the primary role of NGOs was often not education, and that there was a risk of 'education programmes that are not run by people who have education values or pedagogical strengths' (Ireland, formal interview, April 2017). Furthermore, the development of a strong theoretical framework behind educational approaches was perceived as a highly important component of effective teacher education (Ireland, formal interview, April 2017). Such an example highlights an expectation that certain courses require not only subject knowledge in relation to the topics addressed, but also educational expertise that has been derived from actual classroom practice. These examples also suggest a perception from some actors of the importance of bridging the gap between subject knowledge (for example, understanding of migration) and classroom practice (for example, teaching about migration in the primary classroom), and highlights an important role for HEls in supporting the collaboration between the classroom practice of teachers and the subject knowledge of NGOs. 


\section{Conclusion}

In this article, we have shown how GCE has received increased promotion as a means of supporting children and young people to develop their knowledge and understanding of multiple global issues. However, despite this increasing prominence, it is apparent that GCE remains a highly contested notion (Marshall, 2005; Hartung, 2017; Jooste and Heleta, 2017), in part due to its scarce theoretical elaboration. Grounded upon comparative analysis, this article has presented an analysis of the roles of HEls, NGOs and participating teachers in the engagement with three pedagogical narratives of teacher education for global citizenship, as content-based, values-based and competency-based.

From the comparative research, it is evident that the pioneering teacher education programmes under enquiry provided an important space for multiple actors to contribute their specialisms towards supporting teachers in their engagement with GCE. As we argued, collaboration between these stakeholders is critical for the success of teacher education programmes and the achievement of teacher agency. We are aware that teacher agency is not only enhanced by teacher education, but also by personal experiences, values, capacities and relationships. However, a quality, transformative teacher education can be regarded not only as a tool to equip teachers with knowledge, skills and abilities required to improve students' learning, but also as an enabling device for agentic teachers, and an apparatus that may somehow facilitate GCE policy development and school change (Pyhältö et al., 2014).

While responsibility for successful GCE teacher education is posited as a collective endeavour by the formal education system and NGOs, our research and the literature also highlight the risk that contrasting cultures, especially between NGOs and teachers, could lead to conflict that undermines the effectiveness of constructive partnerships between different actors, and diminishes the effect on teachers' agency. HEls could facilitate negotiation between different pedagogical narratives, bridging contrasting cultures and divergent educational goals. Their contribution is critical in providing theoretical clarification that may contrast with the theoretical insufficiency of GCE, in carrying out empirical research on curriculum, assessment and teacher education processes and in framing teacher education within institutional settings through the provision of professional expertise.

Therefore, there is an imperative for $\mathrm{HEl}$ involvement, bringing research, theory and teacher education expertise to the heart of the process. Universities and educational researchers should make their voices heard within this field, through engagement with educational policy and deeper comparative research into the practices, assessment and conceptualization of GCE.

\section{Acknowledgements}

The research team was coordinated by Massimiliano Tarozzi, supported by research assistant Carla Inguaggiato. Data were collected by Martina Novotná (Czech Republic), Benjamin Mallon (Ireland), Carla Inguaggiato and Debora Antonucci (Italy) and Sandra Altenberger (Austria).

This research project took place within the framework of the EU co-funded Global Schools project. Started in 2015, Global Schools was a three-year European teacher education project carried out in $10 \mathrm{EU}$ countries by 17 partners, led by the Autonomous Province of Trento, Italy. It was co-funded by the DEAR Programme of the European Commission. This article refers to the second phase of the research project, 
which built upon an initial phase of comparative teacher education policy analysis across 10 European countries.

\section{Notes on the contributors}

Massimiliano Tarozzi is Co-Director of the Development Education Research Centre at the UCL Institute of Education. He also teaches global citizenship education and general education at the University of Bologna (where he gained his PhD). In the same university, he is Founding Director of the International Research Centre on Global Citizenship Education. He has been studying in the field of intercultural education for more than twenty years, and has extensively published on the topics of global citizenship education, intercultural education, citizenship education, social justice education and qualitative research methods. He has authored with C.A. Torres Global Citizenship Education and the Crises of Multiculturalism (Bloomsbury Academic, 2016).

Benjamin Mallon is Assistant Professor in Development and Intercultural Education in the School of STEM, Innovation and Global Studies in the Institute of Education, Dublin City University. His research explores the theoretical foundations and pedagogical implementation of school-based educational responses to significant global challenges, such as violent conflict, migration and climate change.

\section{References}

Andreotti, V. (2006) 'Soft versus critical global citizenship education'. Policy and Practice: A Development Education Review, 3, 40-51.

Appleyard, N. and McLean, L.R. (2011) 'Expecting the exceptional: Pre-service professional development in global citizenship education'. International Journal of Progressive Education, 7 (2), 6-32.

Biccum, A. (2010) Global Citizenship and the Legacy of Empire: Marketing development. London: Routledge.

Biesta, G.J.J. (2010) 'Why "what works" still won't work: From evidence-based education to valuebased education'. Studies in Philosophy and Education, 29 (5), 491-503.

Biesta, G., Priestley, M. and Robinson, S. (2017) 'Talking about education: Exploring the significance of teachers' talk for teacher agency'. Journal of Curriculum Studies, 49 (1), 38-54.

Bourn, D. (2015) The Theory and Practice of Development Education: A pedagogy for global social justice. London: Routledge.

Bourn, D. (2016) 'Teachers as agents of social change'. International Journal of Development Education and Global Learning, 7 (3), 63-77.

Bryan, A. (2012) 'Band-aid pedagogy, celebrity humanitarianism, and cosmopolitan provincialism: A critical analysis of global citizenship education'. In Wankel, C. and Malleck, S. (eds) Ethical Models and Applications of Globalization: Cultural, socio-political and economic perspectives. Hershey, PA: Business Science Reference, 262-86.

Bryan, A. and Bracken, M. (2011) Learning to Read the World? Teaching and learning about global citizenship and international development in post-primary schools. Dublin: Irish Aid.

Carr, P.R., Pluim, G. and Howard, L. (2014) 'Linking global citizenship education and education for democracy through social justice: What can we learn from the perspectives of teacher-education candidates?'. Journal of Global Citizenship and Equity Education, 4 (1), 1-21.

Castells, M. (2008) 'The new public sphere: Global civil society, communication networks, and global governance'. Annals of the American Academy of Political and Social Science, 616 (1), 78-93.

Clarke, M. and Drudy, S. (2006) 'Teaching for diversity, social justice and global awareness'. European Journal of Teacher Education, 29 (3), 371-86.

Davies, I., Gregory, I. and Riley, S.C. (1999) Good Citizenship and Educational Provision. London: Falmer Press.

Davies, I., Ho, L.-C., Kiwan, D., Peck, C.L., Peterson, A., Sant, E. and Waghid, Y. (eds) (2018) The Palgrave Handbook of Global Citizenship and Education. London: Palgrave Macmillan.

Davies, L. (2006) 'Global citizenship: Abstraction or framework for action?'. Educational Review, 58 (1), 5-25. 
Davies, L., Harber, C. and Yamashita, H. (2005) Global Citizenship Education: The needs of teachers and learners. Birmingham: Centre for International Education and Research.

Engel, L.C. and Siczek, M.M. (2018) 'A cross-national comparison of international strategies: Global citizenship and the advancement of national competitiveness'. Compare: A Journal of Comparative and International Education, 48 (5), 749-67.

EUA (European University Association) (2013) Internationalisation in European Higher Education: European policies, institutional strategies and EUA support. Brussels: European University Association.

European Commission (2007) Key Competences for Lifelong Learning: European Reference Framework. Luxembourg: Office for Official Publications of the European Communities.

Fricke, H.-J., Gathercole, C. and Skinner, A. (2015) Monitoring Education for Global Citizenship: A contribution to debate. Brussels: DEEEP.

Friedman, J.Z. (2018) 'The global citizenship agenda and the generation of cosmopolitan capital in British higher education'. British Journal of Sociology of Education, 39 (4), 436-50.

Fullan, M. (2003) The Moral Imperative of School Leadership. Thousand Oaks, CA: Corwin Press.

GENE (Global Education Network Europe) (2017) The State of Global Education in Europe 2017. Global Education Network Europe. Online. http://tinyurl.com/y62gbchh (accessed 10 April 2019).

George-Jackson, C.E. (2010) 'The cosmopolitan university: The medium toward global citizenship and justice'. Policy Futures in Education, 8 (2), 191-200.

Goren, H. and Yemini, M. (2017) 'Global citizenship education redefined - a systematic review of empirical studies on global citizenship education'. International Journal of Educational Research, 82, 170-83.

Hammond, C.D. and Keating, A. (2018) 'Global citizens or global workers? Comparing university programmes for global citizenship education in Japan and the UK'. Compare: A Journal of Comparative and International Education, 48 (6), 915-34.

Hartung, C. (2017) 'Global citizenship incorporated: Competing responsibilities in the education of global citizens'. Discourse: Studies in the Cultural Politics of Education, 38 (1), 16-29.

Holden, C. and Hicks, D. (2007) 'Making global connections: The knowledge, understanding and motivation of trainee teachers'. Teaching and Teacher Education, 23 (1), 13-23.

Jaeger, H.-M. (2007) '“Global civil society" and the political depoliticization of global governance'. International Political Sociology, 1 (3), 257-77.

Jooste, N. and Heleta, S. (2017) 'Global citizenship versus globally competent graduates: A critical view from the South'. Journal of Studies in International Education, 21 (1), 39-51.

Kaldor, M. (2003) Global Civil Society: An answer to war. Cambridge: Polity Press.

Mannion, G., Biesta, G., Priestley, M. and Ross, H. (2011) 'The global dimension in education and education for global citizenship: Genealogy and critique'. Globalisation, Societies and Education, 9 (3-4), 443-56.

Marshall, H. (2005) 'Developing the global gaze in citizenship education: Exploring the perspectives of global education NGO workers in England'. International Journal of Citizenship and Teacher Education, 1 (2), 76-92.

McCormack, O. and O'Flaherty, J. (2010) 'An examination of pre-service teachers' attitudes towards the inclusion of development education into Irish post-primary schools'. Teaching and Teacher Education, 26 (6), 1332-9.

Niens, U., O'Connor, U. and Smith, A. (2013) 'Citizenship education in divided societies: Teachers' perspectives in Northern Ireland'. Citizenship Studies, 17 (1), 128-41.

O'Connor, L. and Faas, D. (2012) 'The impact of migration on national identity in a globalized world: A comparison of civic education curricula in England, France and Ireland'. Irish Educational Studies, 31 (1), 51-66.

Osler, A. and Vincent, K. (2003) Girls and Exclusion: Rethinking the agenda. London: RoutledgeFalmer.

Oxfam (2015) Education for Global Citizenship: A guide for schools. Oxford: Oxfam. Online. http://tinyurl.com/y3n4souy (accessed 10 April 2019).

Palinkas, L.A., Horwitz, S.M., Green, C.A., Wisdom, J.P., Duan, N. and Hoagwood, K. (2015) 'Purposeful sampling for qualitative data collection and analysis in mixed method implementation research'. Administration and Policy in Mental Health and Mental Health Services Research, 42 (5), 533-44.

Pashby, K. (2011) 'Cultivating global citizens: Planting new seeds or pruning the perennials? Looking for the citizen-subject in global citizenship education theory'. Globalisation, Societies and Education, 9 (3-4), 427-42.

Pike, G. and Selby, D. (1988) Global Teacher, Global Learner. London: Hodder and Stoughton. 
Priestley, M., Biesta, G. and Robinson, S. (2015) Teacher Agency: An ecological approach. London: Bloomsbury Academic.

Pyhältö, K., Pietarinen, J. and Soini, T. (2014) 'Comprehensive school teachers' professional agency in large-scale educational change'. Journal of Educational Change, 15 (3), 303-25.

Richardson, R. (ed.) (1979) Learning for Change in World Society: Reflections, activities and resources. Rev ed. London: World Studies Project.

Robbins, M., Francis, L.J. and Elliott, E. (2003) 'Attitudes toward education for global citizenship among trainee teachers'. Research in Education, 69 (1), 93-8.

Rychen, D.S. and Salganik, L.H. (eds) (2003) Key Competencies for a Successful Life and a WellFunctioning Society. Cambridge, MA: Hogrefe and Huber.

Schattle, H. (2008) The Practices of Global Citizenship. Lanham, MD: Rowman and Littlefield.

Scheunpflug, A. and Asbrand, B. (2006) 'Global education and education for sustainability'. Environmental Education Research, 12 (1), 33-46.

Shultz, L. (2007) 'Educating for global citizenship: Conflicting agendas and understandings'. Alberta Journal of Educational Research, 53 (3), 248-58.

Stein, S. (2015) 'Mapping global citizenship'. Journal of College and Character, 16 (4), 242-52.

Tarozzi, M. and Inguaggiato, C. (2018) 'Implementing global citizenship education in EU primary schools: The role of government ministries'. International Journal of Development Education and Global Learning, 10 (1), 21-38.

Tarozzi, M. and Torres, C.A. (2016) Global Citizenship Education and the Crises of Multiculturalism: Comparative perspectives. London: Bloomsbury Academic.

Tormey, R. and Gleeson, J. (2012) 'The gendering of global citizenship: Findings from a largescale quantitative study on global citizenship education experiences'. Gender and Education, $24(6), 627-45$.

Tota, P.M. (2014) 'Filling the gaps: The role and impact of international non-governmental organisations in "Education for All"'. Globalisation, Societies and Education, 12 (1), 92-109.

UNESCO (United Nations Educational, Scientific and Cultural Organization) (2017) Accountability in Education: Meeting our commitments (Global Education Monitoring Report). Paris: UNESCO Publishing. Online. http://unesdoc.unesco.org/images/0025/002593/259338e.pdf (accessed 10 April 2019).

United Nations (2015) Transforming Our World: The 2030 Agenda for Sustainable Development. New York: United Nations.

Vongalis-Macrow, A. (2007) 'I, teacher: Re-territorialization of teachers' multi-faceted agency in globalized education'. British Journal of Sociology of Education, 28 (4), 425-39.

WHO (World Health Organization) (1993) Life Skills Education for Children and Adolescents in Schools: Introduction and guidelines to facilitate the development and implementation of life skills programmes. Geneva: World Health Organization.

Witteborn, S. (2010) 'The role of transnational NGOs in promoting global citizenship and globalizing communication practices'. Language and Intercultural Communication, 10 (4), 358-72.

Yin, R.K. (2014) Case Study Research: Design and methods. 5th ed. Thousand Oaks, CA: SAGE Publications. 